\title{
Production of a Polyhydroxyalkanoate Biopolymer in Insect Cells with a Modified Eucaryotic Fatty Acid Synthase
}

\author{
MARK D. WILLIAMS, JOHN A. RAHN, AND DAVID H. SHERMAN* \\ Department of Microbiology and Biological Process Technology Institute, \\ 240 Gortner Laboratory, St. Paul, Minnesota 55108-6106
}

Received 20 September 1995/Accepted 11 April 1996

\begin{abstract}
A novel pathway for the synthesis of poly-3-hydroxybutyrate has been engineered by simultaneous delivery of two genes into insect cells (Spodoptera frugiperda) by use of individual baculovirus vectors. This system includes expression of a dehydrase-domain mutant rat fatty acid synthase cDNA and the phbC gene encoding polyhydroxyalkanoate synthase from Alcaligenes eutrophus. The dehydrase-deficient fatty acid synthase provides de novo synthesis of $R$-(-)-3-hydroxybutyryl-coenzyme $A$ as a premature termination product rather than palmityl-coenzyme $A$, the normal product of wild-type rat fatty acid synthase. High levels of this mutant multifunctional protein provide a suitable precursor pool of $\boldsymbol{R}$-(-)-3-hydroxybutyryl-coenzyme A for conversion to poly-3-hydroxybutyrate in insect cells coexpressing the $p h b C$ gene product. This strategy for redesigning a poly-3-hydroxybutyrate biosynthetic pathway suggests a new method for generating structurally diverse polyhydroxyalkanoates by metabolic engineering.
\end{abstract}

Polyhydroxybutyrate (PHB) is a linear polyester of $R-(-)$ 3-hydroxybutyric acid that was first discovered almost 70 years ago (24). It serves as a carbon or energy reserve under limiting nutrient conditions in a variety of gram-positive and gramnegative bacteria (5). PHB is often visualized as electron-dense granules in bacterial cells that can produce the material at levels up to $90 \%$ dry cell weight. PHB was the first identified member of a class of biodegradable thermoplastic storage molecules collectively known as polyhydroxyalkanoates (PHAs). Wallen and Rohwedder (47) identified two 3-hydroxy fatty acids in activated sewage sludge, and later, the presence of at least six 3-hydroxy fatty acids was shown to exist in polymer hydrolysates of batch-grown Bacillus megaterium (3, 8, 13). The structural characteristics imparted by various alkyl groups result in unique physical properties for different PHA polymers $(2,32,41)$.

Although PHB represents the archetypical form of a biodegradable PHA, its unfavorable physical properties (i.e., brittle, low thermal decomposition temperature, low impact strength) preclude significant use of the homopolymeric form. However, copolymers derived from various proportions of 3-hydroxybutyrate and 3-hydroxyvalerate monomers have enhanced physical properties (i.e., greater flexibility, higher thermal decomposition temperature, and higher impact strength) (14). Such copolymers are synthesized when cells are grown in the presence of propionic acid, with the crystallinity of the polymer decreasing as the proportion of hydroxyvalerate increases (14).

Significant progress has been made recently in the cloning, analysis, and expression of genes involved in production of PHB (11, 29, 30, 32, 40, 43). This work has provided an important foundation from which to consider new approaches for production of useful PHAs. In addition, high-level production of PHB has recently been demonstrated in plants by introducing the genes encoding acetoacetyl-coenzyme A (acetoacetyl$\mathrm{CoA})$ reductase $(p h b B)$, PHA synthase $(p h b C)$, and $\beta$-ketothiolase $(p h b A)$ into Arabidopsis thaliana $(27,31,32)$.

\footnotetext{
* Corresponding author. Mailing address: BPTI, 240 Gortner Laboratories, 1479 Gortner Ave., St. Paul, MN 55108-6106. Phone: (612) 625-1901. Fax: (612) 625-1700. Electronic mail address: david$\mathrm{s} @$ biosci.cbs.umn.edu.
}

Although strategies exist for generating PHAs with useful physical properties, they are limited by the expense of specialized feedstocks for bacterial fermentation. There would be considerable advantages to a metabolic engineering strategy which provides synthesis of PHA monomers intracellularly, compared with the traditional approach of feeding specialized precursor feedstocks to bacterial fermentation systems. Toward this end, we considered the possibility that acyl chain biosynthesis by fatty acid and polyketide synthases (PKSs) (15) may provide a versatile overall strategy. The model for this type of approach is represented by the multifunctional rat fatty acid synthase (FAS) (36). It is a homodimer with a subunit structure consisting of 2,505 amino acid residues and a molecular mass of 272,340 Da. Each subunit consists of seven catalytic activities in separate domains (1). Studies of rat FAS led to the recognition of multifunctional proteins as a new class of enzymes with two or more activities associated with a single polypeptide $(21,22,42)$. Further studies involving limited proteolysis of these large multifunctional proteins revealed that some isolated domains retained activities associated with the FAS $(33,37,44)$.

An important issue for producing novel PHAs that have utility and retain their quality as biodegradable and renewable materials is the ability to generate in vivo a diverse range of hydroxyacyl-CoA monomers. Traditional strategies involve feeding short- and long-chain fatty acid monomers to bacterial cultures that are incorporated into the polymer chain to give random copolymers with enhanced physical properties (2). Current technology is limited to the monomeric diversity generated by cells that produce PHAs. $R$ - $(-)$-3-hydroxybutyryl$\mathrm{CoA}$ is a common substrate in many bacteria; however, precursor feeding studies have revealed that some PHA synthases are relatively nonspecific and may polymerize 3-hydroxy-, 4-hydroxy-, and 5-hydroxyalkyl-CoA esters (6, 12, 39, 45). Furthermore, methyl-substituted and unsaturated 3-hydroxyalkyl-CoA esters have also been incorporated into PHA polymers in Pseudomonas oleovorans $(9,10,17)$. A primary challenge for future development of technologies to produce structurally diverse hydroxyacyl-CoA units for homopolymer and copolymer PHAs is the rational construction of monomer pathways that provide an intracellular precursor pool for the PHA syn- 
<smiles>CCCCSC(C)=O</smiles>

$\beta$-ketothiolase

$\downarrow$<smiles>CC(=O)CC(=O)[SeH]</smiles>

\section{acetoacetyl-CoA reductase}<smiles>C[C@@H](O)CC(=O)[GeH2]</smiles><smiles>CCCCCCCCCC</smiles><smiles>C[C@@H](CC(=O)C(C)(C)[18F])OC(C)(C)C</smiles><smiles>CC(=O)CCCCCSC(C)=O</smiles>

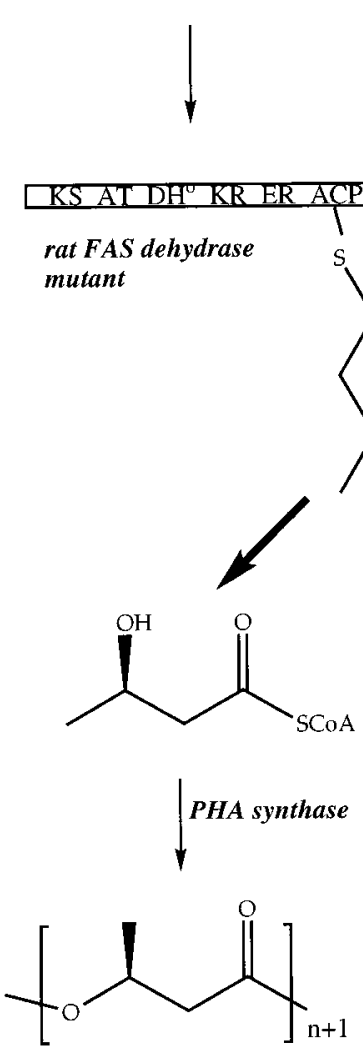

FIG. 1. Comparison of the natural and engineered pathways for PHB synthesis. The three enzymatic steps of PHB synthesis in bacteria involving $\beta$-ketothiolase, acetoacetyl-CoA reductase, and PHB polymerase are shown on the left. The engineered pathway for PHB synthesis in S 21 cells is shown on the right. This involves condensation of acetyl-CoA and malonyl-CoA followed by ketoreduction of acetoacetyl-ACP to give $\beta$-hydroxybutyryl-ACP (16). These reactions are both performed by the rat FAS $\mathrm{DH}^{0}$ multifunctional protein (represented by the open arrow) with catalytic sites abbreviated as follows: KS, $\beta$-ketoacyl synthase domain; AT, acyltransferase domain; $\mathrm{DH}^{0}$, nonfunctional DH domain; KR, ketoreductase domain; ER, enoylreductase domain; TE, thioesterase domain. SCoA, S-coenzyme A.

thase. Although this already occurs in some bacteria through the $\beta$-oxidation pathway of fatty acids, it provides only a limited array of PHA monomers that vary in alkyl chain length but not in the degree of alkyl group branching, unsaturation, or functionalization along the acyl chain. By redirecting a FAS (or polyketide synthase) $(4,16,20)$ multifunctional protein toward premature termination products, it may be possible to generate a predetermined and structurally diverse array of acyl chains for the synthesis of high-utility biodegradable PHAs.

Recently, expression of functionally active rat FAS in a baculovirus-insect cell expression system allowed identification of the dehydrase (DH)-domain active-site His-878 (19). Following site-directed mutagenesis, in vitro studies showed that the DH mutant with His replaced by Ala at position 878 (His-878 $\rightarrow$ Ala) produced 3-hydroxybutyryl-CoA as a premature termination product from acetyl-CoA, malonyl-CoA, and NADPH. We therefore considered the possibility that the rat FAS DH mutant could be a model for a redirected multifunctional protein to provide monomer substrates for PHA biosynthesis.

This report describes the construction of a novel metabolic pathway for the production of PHAs in insect cells. The approach utilizes a DH-deficient $\left(\mathrm{DH}^{0}\right)$ form of rat FAS to pro- duce the PHB monomer, $R$-(-)-3-hydroxybutyrate. This multifunctional protein effectively replaces the $\beta$-ketothiolase and acetoacetyl-CoA reductase activities of the natural procaryotic PHB pathway. Coexpression of the mutant rat FAS cDNA with the wild-type Alcaligenes eutrophus phbC gene results in $\mathrm{PHB}$ production in insect cells.

\section{MATERIALS AND METHODS}

Plasmids, strains, and culture conditions. Plasmid pFAS206 and a recombinant baculoviral clone encoding FAS206 (19) were generous gifts of A. Joshi and S. Smith. Plasmid pAet41 (30), the source of the Alcaligenes eutrophus PHA synthase, was kindly provided by A. Sinskey (Massachusetts Institute of Technology, Cambridge). Baculovirus transfer vector pBacPAK9 and linearized baculoviral DNA were obtained from Clontech Inc. (Palo Alto, Calif.). Restriction enzymes, T4 DNA ligase, Escherichia coli DH5 $\alpha$ competent cells, lipofectin reagent, Grace's insect cell medium, fetal bovine serum, and antibiotic-antimycotic reagent were obtained from GIBCO-BRL (Grand Island, N.Y.). Spodoptera frugiperda (strain Sf21) and BTI-TN-5B1 Trichoplusia ni insect cells were generous gifts from G. Franzen, R\&D Systems (Minneapolis, Minn.) and Stefan Harsch (Department of Veterinary Pathobiology, University of Minnesota), respectively. Tissue culture dishes were obtained from Corning Inc. (Corning, N.Y.). Spinner flasks were obtained from Bellco Glass Inc. (Vineland, N.J.). SeaPlaque GTG agarose was obtained from FMC Bioproducts Inc. (Rockland, Maine).

Construction of pBPphbC. The $p h b C$ gene was excised from pAet41 on an approximately 1.8 -kb fragment (30) by digestion with Bst BI and StuI, purified as 


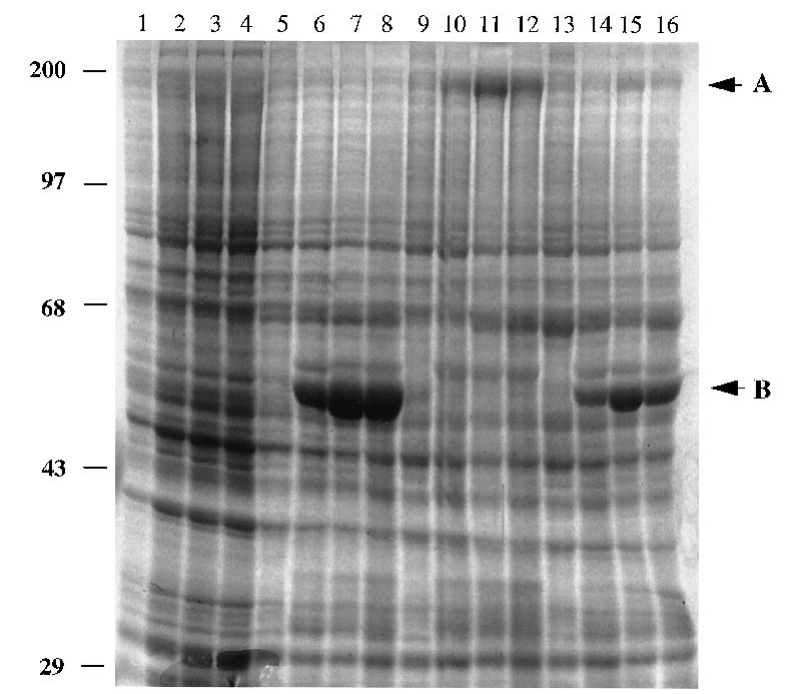

FIG. 2. SDS-PAGE and Coomassie brilliant blue R staining of proteins synthesized at various time points during infection of $\mathrm{S} f 21$ cells. Approximately 0.5 $\mathrm{mg}$ of total cellular protein from various samples was fractionated on a $10 \%$ polyacrylamide gel. Samples include uninfected cells on days $0,1,2$, and 3 (lanes 1 to 4 , respectively), infection with BacPAK6::phbC alone on days $0,1,2$, and 3 (lanes 5 to 8 , respectively), infection with baculoviral clone containing rat FAS206 alone (19) on days $0,1,2$, and 3 (lanes 9 to 12, respectively), and doubly infected cells (rat FAS206, BacPAK6::phbC) on days $0,1,2$, and 3 (lanes 13 to 16, respectively). (A) Rat FAS $\mathrm{DH}^{0}$ protein; (B) PHA synthase. Migration of molecular mass markers (in kilodaltons) is indicated on the left.

described earlier (48), and ligated to pBacPAK9 digested with Bst BI and StuI. This resulted in $\mathrm{pBPphbC}$, the baculovirus transfer vector used in formation of recombinant baculovirus particles carrying $p h b C$

Insect cell maintenance and recombinant baculovirus formation. $\mathrm{S} f 21$ cells were maintained (28) at 26 to $28^{\circ} \mathrm{C}$ in Grace's insect cell medium supplemented with $10 \%$ fetal bovine serum, $1.0 \%$ pluronic $\mathrm{F} 68$, and $1.0 \%$ antibiotic-antimycotic reagent. Cells were maintained in suspension at $0.2 \times 10^{6}$ to $2.0 \times 10^{6} / \mathrm{ml}$ in a 60 -ml total culture volume in $100-\mathrm{ml}$ spinner flasks at 55 to $65 \mathrm{rpm}$. Cell viability during the culture period was typically 95 to $100 \%$, as determined by trypan blue dye exclusion. The procedures for use of the transfer vector and baculovirus were essentially those described by the manufacturer (Clontech). Purified pBPphbC and linearized baculovirus DNA were used to cotransfect $\mathrm{S} f 21$ cells by the liposome-mediated method (7). Four days later, cotransfection supernatants were harvested for subsequent plaque purification. Recombinant viral clones were purified from plaque assay plates containing $1.5 \%$ SeaPlaque GTG after 5 to 7 days at $28^{\circ} \mathrm{C}$. Recombinant viral clone stocks were then amplified in T25 flask cultures $\left(4 \mathrm{ml}, 3 \times 10^{6} / \mathrm{ml}\right.$ on day 0$)$ for 4 days; infected cells were identified morphologically and then screened for production of PHA synthase by sodium dodecyl sulfate-polyacrylamide gel electrophoresis (SDS-PAGE) on $10 \%$ polyacrylamide gels (23) stained with Coomassie brilliant blue R.

Insect cell double-infection protocol. Four $100-\mathrm{ml}$ spinner flasks were each inoculated with $8 \times 10^{7}$ cells in $50 \mathrm{ml}$ of fresh insect cell medium. To flask 1 , an additional $20 \mathrm{ml}$ of fresh insect cell medium was added (uninfected control); to flask $2,10 \mathrm{ml}$ of BacPAK6::phbC viral stock $\left(\approx 10^{8} \mathrm{PFU} / \mathrm{ml}\right)$ and $10 \mathrm{ml}$ of fresh insect cell medium were added; to flask $3,10 \mathrm{ml}$ of BacPAK6::FAS206 viral stock $\left(\approx 10^{8} \mathrm{PFU} / \mathrm{ml}\right)$ and $10 \mathrm{ml}$ of fresh insect cell medium were added; and to flask $4,10 \mathrm{ml}$ of BacPAK6::phbC viral stock $\left(\approx 10^{8} \mathrm{PFU} / \mathrm{ml}\right)$ and $10 \mathrm{ml}$ of BacPAK6:: FAS206 viral stock $\left(\approx 10^{8} \mathrm{PFU} / \mathrm{ml}\right)$ were added. These viral infections were carried out at multiplicities of infection of approximately 10 . Cultures were maintained under normal growth conditions, and 15-ml samples were removed at 24-, 48-, and 72-h time points. Expression of both rat FAS and PHA synthase is under the control of the very late polyhedrin promoter. Very late baculovirus gene expression commences at approximately $24 \mathrm{~h}$ postinfection and continues through 48 to $60 \mathrm{~h}$ postinfection, after which most cells are no longer viable (28). We maintained the cultures to $72 \mathrm{~h}$ in an effort to maximize PHB production. Cells were collected by gentle centrifugation at $1,000 \times g$ for 5 min, the medium was discarded, and the cells were immediately stored at $-70^{\circ} \mathrm{C}$.

PHB assay. PHB was assayed from $\mathrm{S} f 21$ cell samples by the propanolysis method of Riis and Mai (34). Cell pellets were thawed on ice, resuspended in $1 \mathrm{ml}$ of cold distilled deionized $\mathrm{H}_{2} \mathrm{O}$, and transferred to 5-ml screw-top test tubes with Teflon seals. Two milliliters of distilled deionized $\mathrm{H}_{2} \mathrm{O}$ was added, the cells were washed and centrifuged, and then $3 \mathrm{ml}$ of acetone was added and the cells were washed and centrifuged. The samples were then dessicated by placing them in a $94^{\circ} \mathrm{C}$ oven for $12 \mathrm{~h}$. The following day, $0.5 \mathrm{ml}$ of 1,2-dichloroethane, $0.5 \mathrm{ml}$ of acidified propanol $(20 \mathrm{ml}$ of $\mathrm{HCl}, 80 \mathrm{ml}$ of 1-propanol), and $50 \mu \mathrm{l}$ of benzoic acid standard were added and the sealed tubes were heated to $100^{\circ} \mathrm{C}$ in a boiling water bath for $2 \mathrm{~h}$ with periodic vortexing. The tubes were cooled to room temperature, and the organic phase was submitted for gas chromatographic (GC) analysis with a Hewlett-Packard 5890A GC equipped with a HewlettPackard 7673A automatic injector and a fused silica capillary column (DB-WAX $30 \mathrm{~W} ; 30 \mathrm{~m}$ long). Positive samples were further subjected to GC-mass spectrometry (GC-MS) analysis for the presence of propylhydroxybutyrate with a Kratos MS25 GC-MS. The following parameters were used: source temperature, $210^{\circ} \mathrm{C}$ voltage, $70 \mathrm{eV}$; accelerating voltage, $4 \mathrm{keV}$.

Confocal microscopy and immunofluorescence. BTI-TN-5B1-4 T. ni cells were cultured for $44 \mathrm{~h}$ on 12 -mm-diameter glass coverslips that had been treated with $5 \mathrm{mM}$ EDTA. The cells were washed in phosphate-buffered saline (PBS; $137 \mathrm{mM}$ $\left.\mathrm{NaCl}, 1.47 \mathrm{mM} \mathrm{KH}_{2} \mathrm{PO}_{4}, 8.17 \mathrm{mM} \mathrm{Na}_{2} \mathrm{HPO}_{4}, 2.7 \mathrm{mM} \mathrm{KCl}[\mathrm{pH} 7.0]\right)$ for $5 \mathrm{~min}$ and then fixed with paraformaldehyde (4\% paraformaldehyde, $100 \mathrm{mM}$ PBS [pH 7.0]) on ice for $60 \mathrm{~min}$. After fixation, the cells were washed three times for $5 \mathrm{~min}$ each in PBS, permeabilized in methanol for $10 \mathrm{~min}$ at $-20^{\circ} \mathrm{C}$, and allowed to air dry. The cells were then treated with blocking buffer $(5 \%$ glycerol, $5 \%$ normal goat serum [Gibco-BRL], $1 \%$ bovine serum albumin, $1 \%$ cold-water fish gelatin [Sigma Chemical Co., St. Louis, Mo.], 5\% dimethyl sulfoxide in PBS [pH 7.2]) for $30 \mathrm{~min}$ at $37^{\circ} \mathrm{C}$. They were then incubated in the primary antibody (rabbit antiPHA synthase [48] diluted 1:200 in blocking buffer) overnight at $4^{\circ} \mathrm{C}$. After primary antibody incubation, the cells were washed three times for 5 min each in PBS and incubated in the secondary antibody (Cappel goat anti-rabbit fluorescein isothiocyanate 55646 diluted $1: 400$ in blocking buffer) for $2 \mathrm{~h}$ at $37^{\circ} \mathrm{C}$. After secondary antibody incubation, the cells were again washed three times for $5 \mathrm{~min}$ each time in PBS, allowed to air dry, and mounted on glass slides with VectaShield mountant (Vector Labs, Burlingame, Calif.). Immunofluorescent microscopic images were obtained with a Bio-Rad MRC-600 confocal microscope which was equipped with a krypton-argon laser, a Nikon Diaphot inverted microscope, and a Nikon $60 \times$ Plan Apo objective (NA 1.4).

\section{RESULTS}

Coexpression of rat FAS DH ${ }^{0}$ cDNA and $p h b C$ in insect cells. To engineer a monomer pathway for PHA biosynthesis, a strategy was devised to generate PHB by combining the metabolic potential of a multifunctional FAS with PHA synthase from Alcaligenes eutrophus (30). Previous studies di-

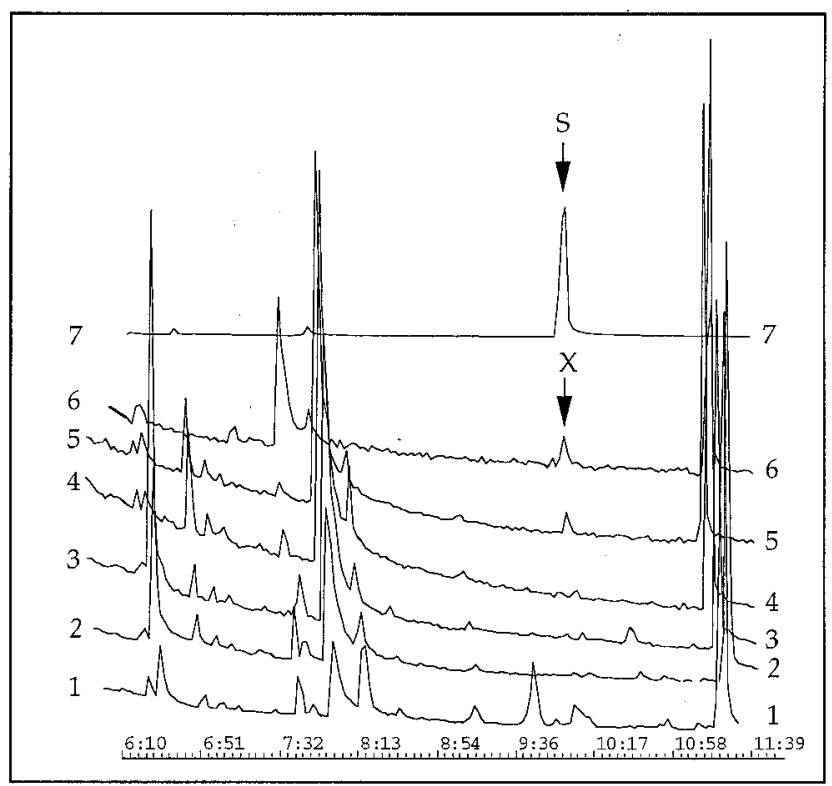

FIG. 3. GC analysis of PHB accumulation in S $f 21$ cells. GCs from various samples are superimposed and labeled 1 to 7 . The PHB standard (Sigma) is chromatogram 7 , showing a propylhydroxybutyrate elution time of $10.0 \mathrm{~min}$ (arrow labeled S). The GC of extracts of the uninfected (chromatogram 1) and single-infected (chromatogram 2, rat $\mathrm{FAS}^{0} \mathrm{DH}^{0}$, day 3; chromatogram 3, PHA synthase, day 3) samples are shown at the bottom. GCs of extracts of doubleinfected cells at days 1 (chromatogram 4), 2 (chromatogram 5), and 3 (chromatogram 6) are also shown exhibiting a peak eluting at $10.0 \mathrm{~min}$ (arrow labeled $\mathrm{X})$. Peak, double-infected, day 3 extract (chromatogram 6) was used for MS analysis. 


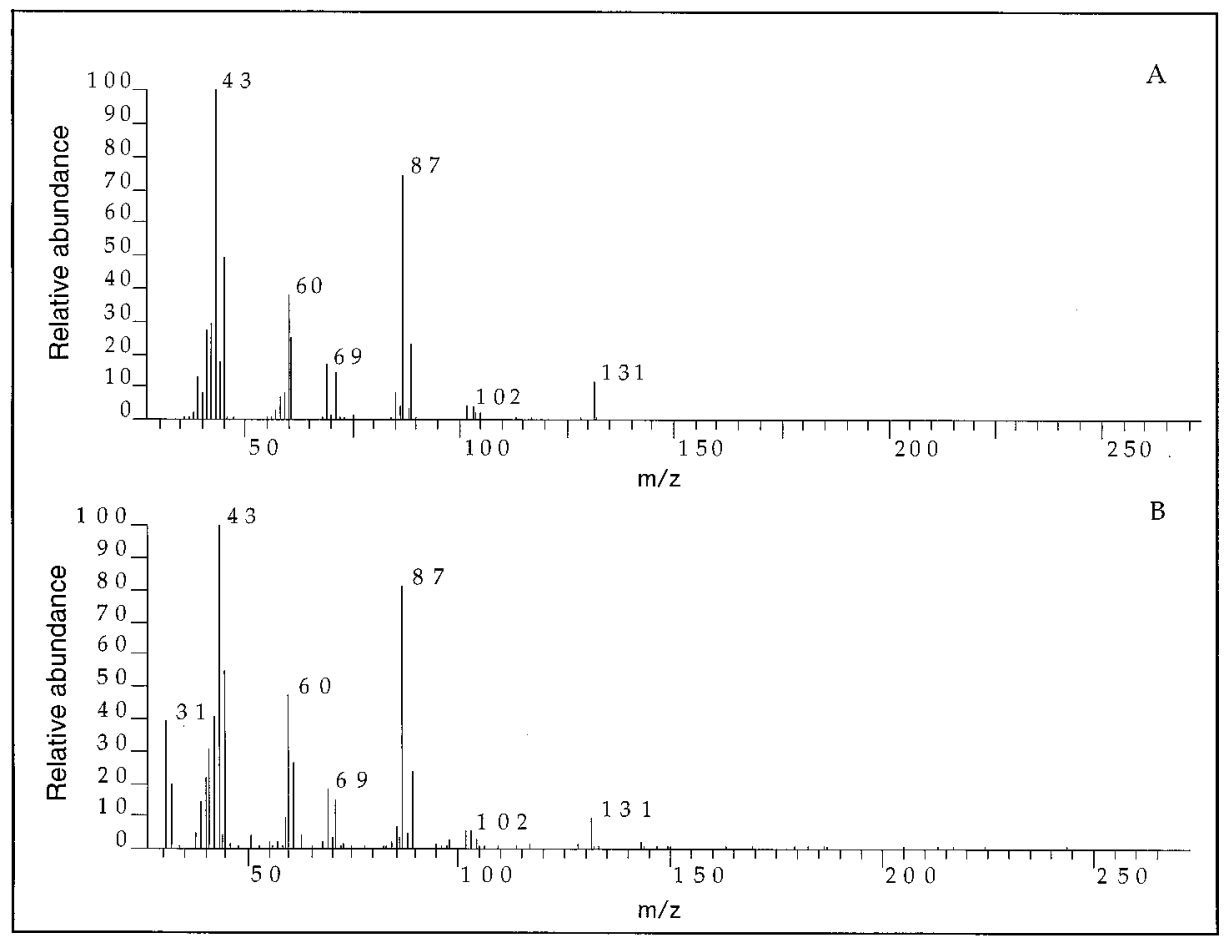

FIG. 4. GC-MS (electron impact) analysis of PHB. The characteristic fragmentation of propylhydroxybutyrate at $m / z$ of $43,60,87$, and 131 is shown. (A) PHB standard (Sigma) from bacteria; (B) peak X from double-infected, day 3 (Fig. 3, chromatogram 6) Sf21 cells expressing rat FAS DH ${ }^{0}$ protein and PHA synthase.

rected toward the identification of a DH-domain active site in the rat FAS resulted in generation of a mutant form of the multifunctional protein that gave 3-hydroxybutyryl-CoA production in vitro (19). However, it was not clear whether a stable pool of 3-hydroxybutyryl-CoA would be formed in vivo to provide suitable substrate levels for polymerization by PHA synthase.

The strategy for engineering a PHB pathway in insect cells compared with the normal pathway for PHB synthesis in $\mathrm{Al}$ caligenes eutrophus is shown in Fig. 1. We decided to investigate whether the His- $878 \rightarrow$ Ala rat FAS $\mathrm{DH}^{0}$ multifunctional protein (19) could replace the procaryotic $\beta$-ketothiolase and acetoacetyl-CoA reductase functions for 3-hydroxybutyrylCoA synthesis. To combine the metabolic functions of the multifunctional rat FAS $\mathrm{DH}^{0}$ protein and the Alcaligenes eutrophus PHA synthase, it was essential to test individual expression of the corresponding genes in $\mathrm{S} f 21$ cells. Production of the active rat FAS $\mathrm{DH}^{0}$ polypeptide in $\mathrm{S} f 9$ cells has been reported previously (19). However, synthesis of active PHA synthase in $\mathrm{S} f 21$ cells remained to be established, and a baculovirus transfer vector ( $\mathrm{pBPphbC}$ ) containing the corresponding gene was generated (see Materials and Methods) (48). Following recombination with linearized baculovirus DNA, a recombinant baculovirus clone which produced high levels of soluble PHA synthase as determined by SDS-PAGE was identified (Fig. 2). Recent studies have shown that Alcaligenes eutrophus PHA synthase must be modified with phosphopantetheine to be catalytically active (11). Since it was unclear whether this procaryotic gene product would be properly modified in insect cells, a series of experiments was performed that confirmed high-level activity of the PHA synthase obtained from Sf21 cell extracts (48).

Once activity of the $p h b C$ gene product had been established, the baculovirus clones containing the rat FAS $\mathrm{DH}^{0}$
cDNA and BacPAK6::phbC were employed in a double infection strategy to determine if PHB would be produced in insect cells. For this to occur, the $R-(-)$-3-hydroxybutyryl-CoA released from rat FAS $\mathrm{DH}^{0}$ protein must be trapped by PHA synthase and converted to polymer at a rate higher than that of $\beta$-oxidation, which would regenerate acetyl-CoA. Another key issue was the stereochemical configuration of the 3-hydroxyl group which must be in the $R$ form to be recognized as a substrate by PHA synthase. Fortunately, previous biochemical studies on eucaryotic FASs indicated that the $R$ form of 3-hydroxylbutyryl-CoA would be generated $(35,46)$. SDS-PAGE of protein samples from a time course of the uninfected (control), single-infected, and double-infected $\mathrm{S} f 21$ cells was performed (Fig. 2). From these data, it is clear that the rat FAS $\mathrm{DH}^{0}$ and PHA synthase polypeptides are efficiently coexpressed in the double-infected $\mathrm{S} f 21$ cells. It is apparent that coexpression results in $\sim 50 \%$ reduced levels of both polypeptides compared with that of $\mathrm{S} f 21$ cells that are producing the individual proteins. Western blot (immunoblot) analysis using anti-rat FAS (18) and anti-PHA synthase antibodies (48) confirmed simultaneous production of the corresponding proteins (data not shown).

Characterization of PHB production in insect cells. To determine if de novo synthesis of PHB was occurring in Sf 21 cells that coexpress the rat FAS $\mathrm{DH}^{0}$ and PHA synthase, fractions of these samples were extracted and the extract was subjected to propanolysis and analyzed for the presence of propylhydroxybutyrate by GC (Fig. 3). A unique peak with a retention time that coincided with that of a propylhydroxybutyrate standard was detected only in the double-infection samples at 48 and $72 \mathrm{~h}$, in contrast to the individually expressed gene products and uninfected controls, which were negative. These samples were analyzed further by GC-MS to confirm the identity of the product. Figure 4 shows MS data corresponding to the 
material obtained from peak 10.1 in the GC compared with that of a propylhydroxybutyrate standard. The results show clearly that PHB synthesis is occurring only in S $f 21$ cells coexpressing the rat FAS $\mathrm{DH}^{0}$ cDNA and the $p h b C$ gene from Alcaligenes eutrophus. Integration of the peak in the GC corresponding to propylhydroxybutyrate revealed that approximately $1 \mathrm{mg}$ of PHB was isolated from a 1-liter culture of Sf21 cells (approximately $600 \mathrm{mg}$ [dry cell weight] of $\mathrm{S} f 21$ cells).

PHB granule formation in insect cells. To provide further evidence that PHB was being produced in insect cells, $T$. $n i$ insect cells coexpressing rat FAS $\mathrm{DH}^{0} \mathrm{cDNA}$ and $p h b C$ were analyzed for the presence of granules. This was accomplished by cell fixation and treatment with anti-PHA synthase antibodies. Granules were clearly observed (Fig. 5A) under these conditions, in contrast to uninfected wild-type $T$. $n i$ cells (Fig. $5 \mathrm{~B}$ ) or in cells individually producing rat FAS $\mathrm{DH}^{0}$ or PHA polymerase polypeptides alone (data not shown). PHB granules of similar sizes and shapes have been observed in bacterial cells (26), transgenic plants (31), and chloroplasts of plant mesophyll cells (27). Taken together, the isolation of PHB and visualization of granules provide compelling evidence of biopolymer formation in insect cells by use of a novel redesigned PHA metabolic pathway.

\section{DISCUSSION}

Previous work by Joshi and Smith (19) established the ability of the rat FAS protein with a His-878 $\rightarrow$ Ala mutation to produce 3-hydroxybutyryl-CoA. This analysis identified the activesite residue of the DH domain in the rat FAS multifunctional protein, thereby confirming the physical location of this elusive catalytic step in fatty acid keto group processing. The results suggested that the rat FAS $\mathrm{DH}^{0}$ protein, although compromised in its absolute function, was still capable of mediating acyl transfer, catalyzing a single-cycle condensation reaction involving acetyl-CoA and malonyl-CoA, and performing ketoreduction on the nascent acetoacetyl-acyl carrier protein (acetoacyl-ACP) intermediate to give 3-hydroxybutyryl-ACP. Although not explicitly addressed, the identification of 3-hydroxybutyryl-CoA in vitro suggested strongly that the premature termination product was released from the mutant protein by transfer to a CoA acceptor (19). The work described in this report was driven by the hypothesis that premature hydroxyacyl-ACP chain elongation intermediates synthesized by FAS (or PKS) multifunctional proteins may provide (after transfer to a CoA acceptor) a novel source of substrates for PHA synthesis.

An important aspect of the current study was expressing in active form the rat FAS $\mathrm{DH}^{0}$ multifunctional protein in concert with the procaryotic PHA synthase from Alcaligenes eutrophus. Although expression of the eucaryotic multifunctional protein in active form had been described previously $(18,19)$, the bacterial enzyme had been expressed only in $E$. coli, albeit relatively poorly. Moreover, recent studies have revealed that catalytically active PHA synthase (11), as with FAS (15), PKS (15), and peptide synthetases (38), requires phosphopantetheine modification of one or more Ser residues. Therefore, the proposed redesigned PHA metabolic pathway required cosynthesis of posttranslationally modified eucaryotic and procaryotic gene products in insect cells. It was therefore significant that PHA synthase can be produced at high levels $(\sim 500-$ fold improvement over that in $E$. coli) in active form by baculoviral expression of the $p h b C$ gene in insect cells (48). In addition, coexpression of multiple gene products in insect cells has been described previously (25).

Although the expression of both rat FAS $\mathrm{DH}^{0}$ and PHA
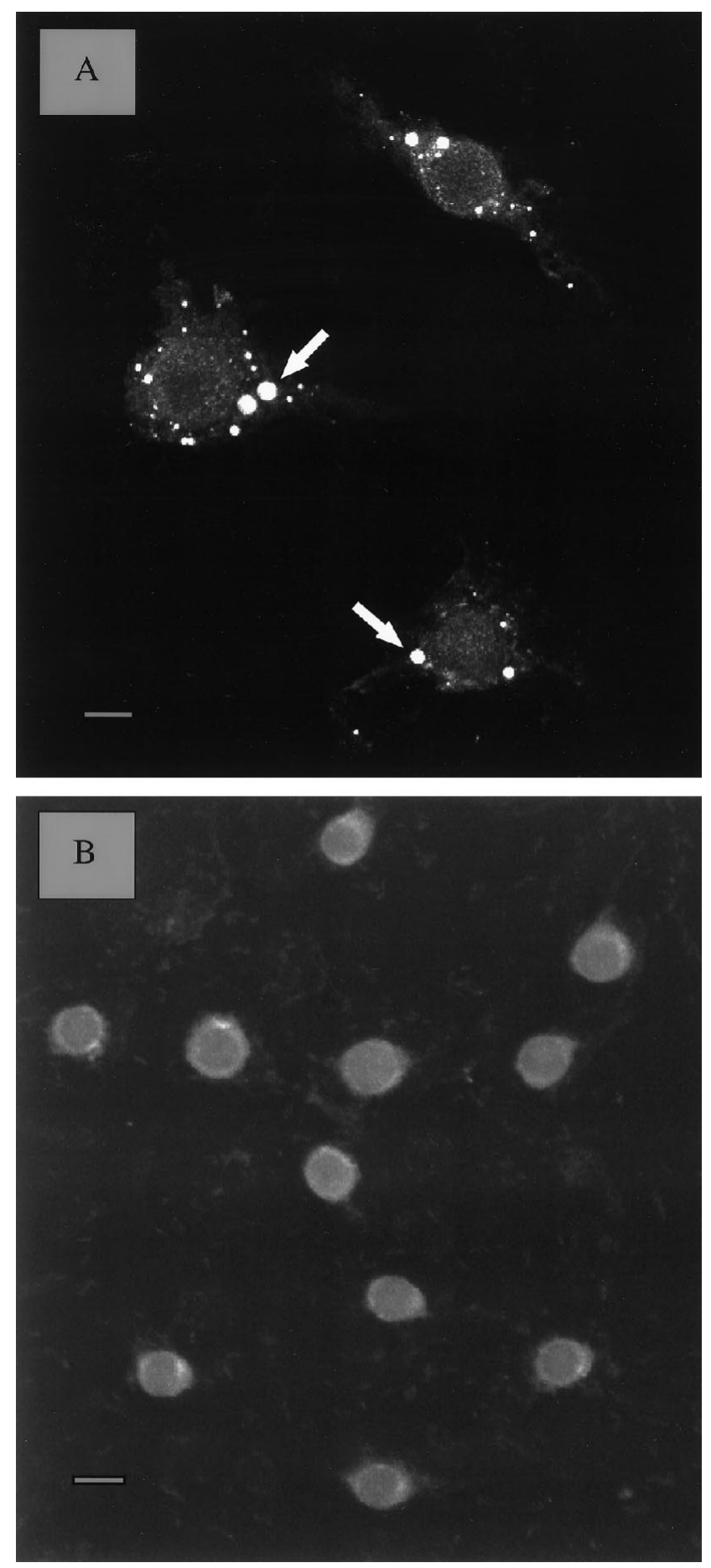

FIG. 5. Immunofluorescent localization of PHB granules in insect cells producing the rat FAS $\mathrm{DH}^{0}$ and PHA synthase polypeptides. (A) T. ni cells coinfected with recombinant baculovirus containing the rat FAS $\mathrm{DH}^{0} \mathrm{cDNA}$ and the PHA synthase gene. Immunofluorescent PHB granules are indicated by the arrows. (B) Uninfected T. $n i$ cells. Bars, $10 \mu \mathrm{m}$.

synthase proteins had been achieved previously in a highly active form, several additional requirements had to be met for successful functioning of the redesigned PHA pathway. First, the stereochemistry of the hydroxyl group required the $R$ configuration for the 3-hydroxybutyryl-CoA to be a substrate for 
PHA synthase. The $R$ configuration for the hydroxyl group during keto group processing in the multifunctional FAS had been established previously. However, it was not clear, a priori, whether synthesis of the 3-hydroxybutryl-ACP chain elongation intermediate and transfer to a CoA acceptor followed by in vivo polymerization would be more rapid than $\beta$-oxidation of 3-hydroxybutyryl-CoA to two molecules of acetyl-CoA. The results of this study show that PHA synthase effectively competes for its substrate and suggests that the kinetics of polymerization is at least similar to or more rapid than catabolism of 3-hydroxybutyryl-CoA in insect cells.

This work provides an important starting point for the design of more complex acyl-CoA monomer synthase from FAS or PKS multifunctional proteins in which premature termination of a biosynthetic pathway is specifically engineered to provide suitably modified acyl-CoA monomers for PHA synthesis. This strategy may be applicable to both procaryotic and eucaryotic (including plant) expression systems, since the formation of biopolymer will not be dependent on specialized feedstocks. Thus, once an engineered PHA monomer pathway gene cassette is introduced into a bacterial or plant system, and coexpression with the appropriate PHA polymerase is achieved, novel biopolymer formation may be explored. Thus, the strategy described herein suggests a new way to harvest metabolic diversity provided by FAS or PKS multifunctional proteins involved in the construction of hydroxyacyl-CoA chains and to tap a significant new source of diversity for novel PHA bioplastics.

\section{ACKNOWLEDGMENTS}

We are indebted to Stuart Smith and Anil Joshi (Children's Hospital Oakland Research Institute, Oakland, Calif.) for providing pFAS206 used in these studies and for helpful discussions

This work was supported by a University Exploratory Research Program grant to D.H.S. from The Procter and Gamble Company.

\section{REFERENCES}

1. Amy, C. M., A. Witkowski, J. Naggert, B. Williams, Z. Randhawa, and S. Smith. 1989. Molecular cloning and sequencing of cDNAs encoding the entire rat fatty acid synthase. Proc. Natl. Acad. Sci. USA 86:3114-3118.

2. Anderson, A. J., and E. A. Dawes. 1990. Occurrence, metabolism, metabolic role, and industrial uses of bacterial polyhydroxyalkanoates. Microbiol. Rev. 54:450-472.

3. Brandl, H., R. A. Gross, R. W. Lenz, and R. C. Fuller. 1990. Plastics from bacteria and for bacteria: poly( $\beta$-hydroxyalkanoates) as natural, biocompatible, and biodegradable polyesters. Adv. Biochem. Eng. Biotechnol. 41:77-93.

4. Cortes, J., K. E. H. Wiesmann, G. A. Roberts, M. J. B. Brown, J. Staunton, and P. F. Leadlay. 1995. Repositioning of a domain in a modular polyketide synthase to promote specific chain cleavage. Nature (London) 268:14871489.

5. Dawes, E. A., and P. J. Senior. 1973. The role and regulation of energy reserve polymers in microorganisms. Adv. Microb. Physiol. 10:135-266.

6. Doi, Y., A. Segawa, and M. Kunioka. 1990. Biosynthesis and characterization of poly(3-hydroxybutyrate-co-4-hydroxybutyrate) in Alcaligenes eutrophus. Int. J. Biol. Macromol. 12:106-111.

7. Felgner, P., T. Gadek, M. Holm, R. Roman, H. Chan, M. Wenz, J. Northrop, G. Ringold, and M. Danielson. 1987. Lipofection: a highly efficient lipidmediated DNA-transfection procedure. Proc. Natl. Acad. Sci. USA 84:74137417.

8. Findlay, R. H., and D. C. White. 1983. Polymeric beta-hydroxyalkanoates from environmental samples and Bacillus megaterium. Appl. Environ. Microbiol. 45:71-78.

9. Fritzsche, K., R. W. Lenz, and R. C. Fuller. 1990. Production of unsaturated polyesters by Pseudomonas oleovorans. Int. J. Biol. Macromol. 12:85-91.

10. Fritzsche, K., R. W. Lenz, and R. C. Fuller. 1990. Bacterial polyesters containing branched poly(beta-hydroxyalkanoate) units. Int. J. Biol. Macromol. 12:92-101.

11. Gerngross, T. U., K. D. Snell, O. P. Peoples, A. J. Sinskey, E. Csuhai, S. Masamune, and J. Stubbe. 1994. Overexpression and purification of the soluble polyhydroxyalkanoate synthase from Alcaligenes eutrophus: evidence for a required posttranslational modification for catalytic activity. Biochemistry 33:9311-9320.

12. Haywood, G. W., A. J. Anderson, and E. A. Dawes. 1989. The importance of
PHB-synthase substrate specificity in polyhydroxyalkanoate synthesis in $\mathrm{Al}$ caligenes eutrophus. FEMS Microbiol. Lett. 57:1-6.

13. Herron, J. S., J. D. King, and D. C. White. 1978. Recovery of poly- $\beta$-hydroxybutyrate from environmental sludge. Appl. Environ. Microbiol. 35:251257.

14. Holmes, P. A., L. F. Wright, and S. H. Collins. 1981. European patent specification 00052459

15. Hopwood, D. A., and D. H. Sherman. 1990. Molecular genetics of polyketides and its comparison to fatty acid biosynthesis. Annu. Rev. Genet. 24:37-66.

16. Huber, M. L. B., J. W. Paschal, J. P. Leeds, H. A. Kirst, J. A. Wind, F. D. Miller, and J. R. Turner. 1990. Branched-chain fatty acids produced by mutants of Streptomyces fradiae, putative precursors of the lactone ring of tylosin. Antimicrob. Agents Chemother. 34:1535-1541.

17. Huijberts, G. N. M., G. Eggink, P. de Waard, G. W. Huisman, and B Witholt. 1992. Pseudomonas putida KT2442 cultivated on glucose accumulates poly(3-hydroxyalkanoates) consisting of saturated and unsaturated monomers. Appl. Environ. Microbiol. 58:536-544.

18. Joshi, A., and S. Smith. 1993. Construction of a cDNA encoding the multifunctional animal fatty acid synthase and expression in Spodoptera frugiperda cells using baculoviral vectors. Biochem. J. 296:143-149.

19. Joshi, A., and S. Smith. 1993. Construction, expression, and characterization of a mutated animal fatty acid synthase deficient in the dehydrase function. J. Biol. Chem. 268:22508-22513.

20. Kao, C. M., G. L. Luo, L. Katz, D. E. Cane, and C. Khosla. 1994. Engineered synthesis of a triketide lactone from an incomplete modular polyketide synthase. J. Am. Chem. Soc. 116:11612-11613.

21. Kirschner, K., and H. Bisswanger. 1976. Multifunctional proteins. Annu. Rev. Biochem. 45:143-166.

22. Knobling, A., D. Schiffman, H.-D. Sickinger, and E. Schweizer. 1975. Malonyl and palmityl transferase-less mutants of the yeast fatty acid synthetase. Eur. J. Biochem. 56:359-364.

23. Laemmli, U. K. 1970. Cleavage of structural proteins during the assembly of the head of bacteriophage T4. Nature (London) 227:680-685.

24. Lemoigne, M. 1926. Produit de déshydration et de polymérisation de l'acide ß-oxybutyrique. Bull. Soc. Chim. Biol. (Paris) 8:770-782.

25. Loudon, P. T., and P. Roy. 1991. Assembly of five bluetongue virus proteins expressed by recombinant baculoviruses: inclusion of the largest protein VP1 in the core and virus-like particles. Virology 180:789-802.

26. Lundgren, D. G., R. M. Pfister, and J. M. Merrick. 1964. Structure of poly- $\beta$-hydroxybutyric acid granules. J. Gen. Microbiol. 34:441-446.

27. Nawrath, C., Y. Poirier, and C. Somerville. 1994. Targeting of the polyhydroxybutyrate biosynthetic pathway to the plastids of Arabidopsis thaliana results in high levels of polymer accumulation. Proc. Natl. Acad. Sci. USA 91:12760-12764.

28. O'Reilly, D. R., L. K. Miller, and V. A. Luckow. 1992. Baculovirus expression vectors: a laboratory manual. W. H. Freeman and Co., New York.

29. Peoples, O. P., and A. J. Sinskey. 1989. Poly- $\beta$-hydroxybutyrate biosynthesis in Alcaligenes eutrophus H16. Characterization of the genes encoding $\beta$-ketothiolase and acetoacetyl-CoA reductase. J. Biol. Chem. 264:15293-15297.

30. Peoples, O. P., and A. J. Sinskey. 1989. Poly- $\beta$-hydroxybutyrate (PHB) biosynthesis in Alcaligenes eutrophus H16. Identification and characterization of the PHB polymerase gene $(p h b C)$. J. Biol. Chem. 264:15298-15303.

31. Poirier, Y., D. E. Dennis, K. Klomparens, and C. Somerville. 1992. Poly- $\beta$ hydroxybutyrate, a biodegradable thermoplastic, produced in transgenic plants. Science 256:520-523.

32. Poirier, Y., C. Nawrath, and C. Somerville. 1995. Production of polyhydroxyalkanoates, a family of biodegradable plastics and elastomers, in bacteria and plants. Bio/Technology 13:142-150.

33. Rangan, V. S., A. Witkowski, and S. Smith. 1991. Isolation of a functiona transferase component from the rat fatty acid synthase by limited trypsinization of the subunit monomer. J. Biol. Chem. 266:19180-19185.

34. Riis, V., and W. Mai. 1988. Gas chromatographic determination of poly- $\beta$ hydroxybutyric acid in microbial biomass after hydrochloric acid propanolysis. J. Chromatogr. 445:285-289.

35. Sedgwick, B., C. Morris, and S. J. French. 1978. Stereochemical course of dehydration catalyzed by yeast fatty acid synthase. Chem. Commun. (J. Chem. Soc. Sect. D) 1978:193-194.

36. Smith, S. 1994. The animal fatty acid synthase: one gene, one polypeptide, seven enzymes. FASEB J. 8:1248-1259.

37. Smith, S., E. Agradi, L. Libertini, and K. N. Dileepan. 1976. Specific release of the thioesterase component of the fatty acid synthetase multienzyme complex by limited trypsinization. Proc. Natl. Acad. Sci. USA 73:1184-1188.

38. Stachelhaus, T., and M. Marahiel. 1995. Modular structure of genes encoding multifunctional peptide synthetases required for non-ribosomal peptide synthesis. FEMS Microbiol. Lett. 125:3-14.

39. Steinbüchel, A. 1991. Polyhydroxyalkanoic acids, p. 123-213. In D. Byrom (ed.), Biomaterials: novel biomaterials from biological sources. MacMillan Publishers Ltd., Basingstoke, United Kingdom.

40. Steinbüchel, A., and H. G. Schlegel. 1991. Physiology and molecular genetics of poly(beta-hydroxy-alkanoic acid) synthesis in Alcaligenes eutrophus. Mol. Microbiol. 5:535-542.

41. Steinbüchel, A., and H. E. Valentin. 1995. Diversity of bacterial polyhydroxy- 
alkanoic acids. FEMS Microbiol. Lett. 128:219-228.

42. Stoops, J. K., M. J. Arslanian, Y. H. Oh, K. C. Aune, T. C. Vanaman, and S. J. Wakil. 1975. Presence of two polypeptide chains comprising fatty acid synthetase. Proc. Natl. Acad. Sci. USA 72:1940-1944.

43. Tomita, K., T. Saito, and T. Fukui. 1983. Bacterial metabolism of poly- $\beta-$ hydroxybutyrate, p. 353-366. In D. Leeon, F. Stratman, and R. Zahlten (ed.), Biochemistry of metabolic processes. Elsevier Press, Amsterdam.

44. Tsukamoto, Y., and S. Wakil. 1988. Isolation and mapping of the $\beta$-hydroxyacyl dehydratase activity of chicken liver fatty acid synthase. J. Biol. Chem. 263:16225-16229.
45. Valentin, H. E., A. Schönebaum, and A. Steinbüchel. 1992. Identification of 4-hydroxyvaleric acid as a constituent in biosynthetic polyhydroxyalkanoic acids from bacteria. Appl. Microbiol. Biotechnol. 36:507-514.

46. Wakil, S. J., and R. Bressler. 1962. Studies on the mechanism of fatty acid synthesis. J. Biol. Chem. 237:687-693.

47. Wallen, L. L., and W. K. Rohwedder. 1974 . Poly- $\beta$-hydroxyalkanoate from activated sludge. Environ. Sci. Technol. 8:576-579.

48. Williams, M. D., A. M. Fieno, R. A. Grant, and D. H. Sherman. 1996 Expression and analysis of a bacterial poly(hydroxyalkanoate) synthase in insect cells using a baculovirus system. Protein Expr. Purif. 7:203-211. 